\title{
THE SAVINGS-TRADE-FISCAL GAP MODEL: APPLICATION IN SELECTED WEST AFRICAN STATES
}

\author{
Obukohwo Oba Efayena \\ Department of Economics \\ University of Nigeria, Nsukka, Nigeria \\ economix4life@gmail.com \\ Ngozi Patricia Buzugbe \\ Department of General Studies \\ Delta State Polytechnic, Ogwashukwu, Nigeria \\ buzugbengozi@gmail.com
}

\begin{abstract}
With most African economies experiencing adverse economic misalignment in recent times, the need of enhancing the growth process cannot be overemphasized. Using a typical Savings-TradeFiscal Gap Model, the paper employed panel data estimation method to examine the impact of savings, trade and fiscal gap on economic growth of 15 West African countries. The paper finds a negative relationship between net trade and economic growth, while savings and government expenditure impacts positively on economic performance. The paper thus, among recommended that it is appropriate for all countries to eliminate fiscal dominance from monetary policymaking, reduce public debt and establish institutions that promote and encourage countercyclical fiscal policy, develop their financial systems, establish credibility in fiscal and monetary policy-making as well as encourage trade.
\end{abstract}

\section{Keywords}

fiscal gap; fiscal policy; panel; growth; savings; capital

\section{JEL Classification}

$\mathrm{H} 51 ; \mathrm{I} 32$

\section{Section title Introduction}

A general belief held in modern society is that economic growth hinges on an effective and efficient financial sector that attract domestic savings and mobilizes funds from external sources. Without such a fulcrum in place, productive project remains unexploited. Because the financial institutions in most developing economies especially in African are inefficient, growth level has been cut higher levels given appropriate policies. While the financial sector is given much priority in most of such economies, the trade (local and international) and fiscal sectors have received reduced attention in the past. Experiences have so far shown that the need for a saving, trade and fiscal model cannot be overemphasized given the failure of most financial institutions in developing economies.

This paper will thus examine the empirics of the 3-gap model of savings, trade and fiscal trends. Following the introductory part, Section 2 develops the typical 3-gap model, Section 3 shows an empirical application of the model to the Nigerian economy, while Section 4 concludes and offer policy recommendation. 


\section{The model}

In a typical developing economy, four flows are identified which include private savers and investors, the financial system, the government, and the foreign sector. It is assumed that private saving is channeled to higher bank deposits, increases in the stock of narrowly defined money, or asset holdings abroad through capital flight. The financial side of the economy is treated as a pure credit banking system. This can be clearly seen in the Chenery and Strout Two-Gap Model.

Following assumption of Rostow (1956) let $A_{p}$ be bank assets (credit, loans) advanced to the private sector, $A_{g}$ be advances to the government, and $e_{R}$ be the values of foreign reserves. Bank liabilities are deposits (D) and narrow money (M). Therefore, the banking system balance sheet is;

$$
A_{p}+A_{g}+e_{R}=D+M
$$

Analyzing equation (1) in flow terms,

$$
\dot{A_{p}}+\dot{A_{g}}+\dot{e} R=\dot{D}+\dot{M}
$$

Where a "dot" over a variable denotes its time derivatives,

Savings (s) is some constant proportion, s, of national income (y) such that

$$
S=s Y
$$

But Investment (I) defined as a change into the capital stock, K, is in accordance with the acceleration principle measured and assumed to be a constant of the rate of growth of output so that,

$$
\begin{aligned}
& I=\Delta K=k\left(Y_{t}-Y_{t-1}\right) \\
& I=\Delta K=k \Delta Y
\end{aligned}
$$

Where k stands for the marginal capital coefficient or simply the incremental capitaloutput ratio (ICOR) and $\Delta$ indicates a change in the variable.

Dividing equation (3) by $\mathrm{Y}$ yields.

$$
\frac{I}{Y}=\frac{\Delta K}{Y}=k \frac{\Delta Y}{Y}
$$

Rewriting (equ. 4) by substituting $\Delta \mathrm{K}$ for I,

$$
\frac{I}{Y}=k \frac{\Delta Y}{Y}
$$

Rewriting $\frac{\Delta Y}{Y}$ as g, the rate of growth of output can be expressed as

$$
g=\frac{1}{k}
$$

On the assumptions that $\mathrm{k}$ is fixed, based on the assumption that the production function is of fixed proportions, the only constraint to growth is investment capital, hence, is seen as a bottleneck to growth (Chenery and Strout, 1966). Real Investment I in turn is the sum of $I_{p}+I_{g}$ (private and public capital formation). Let $I_{g}=\kappa K$ be the government's investment decision. Its own capital formation is set as a share of $\kappa$ of 
the total capital stock. The value of private investment is $(g-\kappa) P K$ and we assume that the banks issue a new loan $\dot{A}_{p}$ to finance the increase in private capital;

$$
\frac{A_{p}}{P K}=g-\kappa
$$

The overall investment function determining $\mathrm{g}$ is presented as a reduced form (depending on credit availability among other factors).

Let real government current spending $G=\gamma K$

Where $\gamma$ as a proxy for the non-investment fiscal deficit or government dis-savings. The government also borrows abroad. Its outstanding stock of loans is F upon which it pays an interest rate $r$. If the debt growth rate $F$ exceeds the interest rate $r$, the government turns to the banks to finance the part of its spending it cannot cover with foreign loans expressed below;

$$
\frac{\dot{A_{g}}}{P K}=\kappa+\gamma-T
$$

Domestic borrowing can be a substantial share of GDP when T is less than zero. Debtor country governments owe large foreign obligations but do not own the resources to generate foreign exchange to pay. The outcome is a severe fiscal crunch.

Finally on the bank asset side, the increase in reserves is

$$
\frac{e \dot{R}}{P K}=T+\varepsilon-a u-(1-\theta) g-Q
$$

Where $\varepsilon=\frac{E}{K}$ is the ratio of exports (net of competitive imports) to capital stock. Imports go only for intermediates goods $(a u)$ and capital goods $(1-\theta) g$, and $Q$ stands for net acquisition of foreign assets (relative to the capital stock) by the private sector.

To describe the saving gap, we assume that saving desired by nationals in the absence of price inflation is directed either to foreign asset accumulation or else to increased bank deposits, such that;

$$
Q+\frac{\dot{D}}{P K}=\left[\pi s_{\pi}+(1+\pi)(1-\theta) s_{w}\right] u=s(\pi, \theta) u
$$

Where $S_{\pi}$ and $S_{w}$ are the saving rates from profit and wage income flows respectively. $\theta=\frac{e a}{(e a+w b)}$ is the share of intermediate imports respectively in variable cost, so that $(1+\pi)(1-\theta) u$ is the ration of the wage bill to the capital stock. If the share $\lambda$ of saving flows abroad, the equation above becomes;

$$
\frac{\dot{D}}{P K}=(1-\lambda) s u
$$

Putting equation (2) and (10) together shows that the increase in the supply of narrow money is 


$$
\begin{aligned}
& \frac{\dot{M}}{P K}=g+\gamma-(1-\lambda) s u+[\varepsilon-a u-(1-\theta) g] \\
& =g+\gamma-(1-\lambda) s u+\left[\frac{e \dot{R}}{P K}-T\right]
\end{aligned}
$$

where the terms in the bracket represent the balance of payments (net of capital flight) on current and capital account.

Relative to capital stock, we assume that private investment demand is given by the function;

$$
\frac{I_{P}}{K}=g_{0}+a u+\beta\left(\frac{I_{g}}{K}\right)+\varphi\left[\left(\frac{\dot{D}}{P K}\right)-\left(\frac{\dot{A_{g}}}{P K}\right)\right]
$$

The term $a u$ is an instantaneous accelerator, $\frac{I_{g}}{K}$ shows that public investment crowds in private capital formation because of complementarities and other external effects.

The last term $\left(\frac{A_{g}}{P K}\right)$ in equation (15) introduces financial crowding-out as a potential counterpoise to direct crowding-in. It is assumed along conventional lines that investment is cut back when government puts pressure on financial markets.

Specifically, $I_{P}$ falls when a new government borrowing $\frac{A_{g}}{P K}$ grows with respect to the deposit increase $\frac{\dot{D}}{P K}$. The rationale could be that banks raise interest rate and tighten credit limits more of their deposit base is absorbed by the government. This simple flow specification is dimensionally equivalent to the quantity theory of money demand and saves the use of asset stock.

Uniting equation (7), (10) and (12) in its simplified form;

$$
-g+g_{0}+[a+\varphi(1-\lambda) s] u+(1+\beta-\varphi) \kappa-\varphi \gamma+\varphi T=0
$$

Thus relationship shows that the capital stock growth rate $g$ increases endogenously in response to greater capacity utilization $u$ due to the accelerator and also because higher private saving creates deposits which banks use to finance investments.

Government investment $\kappa$ has an overall crowding-in effect if

$$
1+\beta>\varphi \text {. }
$$

This condition will be satisfied if

$$
\beta \geq 1 \text { And if } \varphi \geq 1
$$

Also, an increase in foreign transfers T or a reduction in government dis-savings $\gamma$ cuts back on public borrowing from the banks, again permitting private investment to rise. A third gap, which is the fiscal gap, was also explored for its independent constraining influence on the growth of an economy. To an extent, a fiscal gap can directly constrain economic growth, influence the trade gap and therefore make an indirect impact on the economy. However, the fiscal constraint in a three gap model is often predicted on the assumptions that the public and private investments (Blejer and Khan 1984; Barro 
1989) are complementary to each other and the savings are forced through inflation. Within the three-gap simulation analysis of foreign resources flows, Taylor (1993) convincingly concludes that a 'substantial realignment in international payments would be required to accelerate the growth for developing nations overall'.

Employing these assumptions in a two gap framework, Bacha (1990) argues that foreign transfers are more important than foreign savings. This explains why the IMF and the World Bank continues to emphasize on how to contain the inflationary pressures through light fiscal and monetary policies. In less developed countries (LDCs), there exists a market for government bonds however thin it may be while the governments continues to resort to a partial monetization of budget deficits, they also access market borrowing thorough open market operations.

\section{Model specification}

\section{Analytical framework and empirical model specification}

This analysis is carried out within a panel data estimation framework. The preference of this estimation method is not only because it enables a cross-sectional time series analysis which usually makes provision for broader set of data points, but also because of its ability to control for heterogeneity and endogeneity issues. Hence panel data estimation allows for the control of individual-specific effects usually unobservable which may be correlated with other explanatory variables included in the specification of the relationship between dependent and explanatory variables (Hausman and Taylor, 1981). The basic framework for panel data regression takes the form:

$\mathrm{Y}_{\mathrm{it}}=\beta \mathrm{X}_{\mathrm{it}}^{1_{\mathrm{it}}}+\alpha \mathrm{Z}_{\mathrm{i}}^{1}+\varepsilon_{\mathrm{it}}$

In equation 14 above, the heterogeneity or individual effect is $Z_{i}$ ' which may represent a constant term and a set of observable and unobservable variables. When the individual effect $Z_{i}$ ' contains only a constant term, OLS estimation provides a consistent and efficient estimates of the underlying parameters (Kyereboah-Coleman, 2007); but if $\mathrm{Z}_{\mathrm{i}}$ ' is un-observable and correlated with $X_{\text {it }}$, then emerges the need to use other estimation method because OLS will give rise to biased and inconsistent estimates.

Similarly for endogeneity issues, it is generally assumed that the explanatory variables located on the right hand side of the regression equation are statistically independent of the disturbance $\varepsilon_{\text {it }}$ such that the disturbance term $\varepsilon_{\text {it }}$ is assumed to be uncorrelated with columns of the parameters $X_{\text {it }}$ and $Z_{\text {it }}$ as stated in equation (1), and has zero mean and constant variance $\sigma^{2} \eta$ (Hausman and Taylor, 1981; Nakamura and Nakamura, 1981). If this assumption is violated, then OLS estimation will yield biased estimates of the underlying parameters of $\beta$ (Mayston, 2002).

Hence, endogeneity problems arise when the explanatory variables are correlated with the disturbance term $\varepsilon_{i t}$ (Mayston, 2002; Nakamura and Nakamura, 1981; Hausman and Taylor, 1981). In order to circumvent these problems, panel estimation techniques of fixed and random effects will be adopted in this study, in addition to the traditional pooled regression estimation. Decisions will be made between the fixed and random effect models using the Hausman specification test.

The panel model for the study is specified thus:

$\mathrm{EG}_{\mathrm{it}}=\beta_{0}+\beta_{1} \mathrm{X}_{\mathrm{it}}+\mu_{\mathrm{it}}$

Where:

$\mathrm{EG}=$ economic growth

$X^{\prime}=$ collate of explanatory variables; Savings, Trade and Fiscal gap (government expenditure)

$\beta_{0}=$ intercept

$\beta_{1}=$ coefficient of the explanatory variable 
$\mu=$ error term

$\mathrm{i}=$ cross-sectional variable

$\mathrm{t}=$ time series variable $(1990-2015)$

\section{Interpretation of regression analysis}

In this section we employed panel data estimation method to examine the impact of savings, trade and fiscal gap on economic growth of 15 West African countries (Benin, Burkina Faso, Cameroon, Cape Verde, Central African Republic, Cote d'Ivoire, Gambia, Ghana, Guinea, Liberia, Mali, Mauritania, Niger, Nigeria and Senegal) from 1990 to 2015. The study considered the pooled regression assuming that the intercept is equal across the countries areas and years. We also assume different intercept for each country and perform both Fixed and Random Effect regressions. This is presented below;

Table 1 Panel Results for the Savings-Trade-Fiscal Gap Model

\begin{tabular}{l|c|c|c}
\hline \multicolumn{1}{c|}{ Variable } & Pooled & Fixed Effect & Random Effect \\
\hline AS & $0.502^{* *}$ & $0.617^{* *}$ & $0.813^{* *}$ \\
NT & -0.037 & $-0.015^{*}$ & -0.009 \\
GE & 0.037 & 0.030 & $0.027^{*}$ \\
Cons & $0.452^{* *}$ & $0.719^{*}$ & $0.274^{*}$ \\
\hline No. of Obs & 15 & 15 & 15 \\
\hline R-Square & 0.3598 & 0.2941 & 0.4571 \\
\hline F-Statistics & $6.28(0.011)$ & $4.93(0.066)$ & $17.31(0.008)$ \\
value) & \multicolumn{3}{|c}{$0.83(0.8821)$} \\
Hausman & \multicolumn{2}{c}{ Source: EView 8 Output }
\end{tabular}

Table 1 above presents the relationship between savings, net trade and government and economic growth in 15 West African states. The F-statistics value of $6.28(\mathrm{P}<0.05)$, $4.93(\mathrm{P}<0.05)$ and $17.31(\mathrm{P}<0.05)$ show that the independent variables are jointly statistically significant in the Pooled, Fixed and Random estimates in explaining variations in economic growth. The R-square statistics value of $0.3598,0.2941$, and 0.4571 shows that the independent variables jointly account for about $35.9 \%, 29.4 \%$ and $45.7 \%$ variation on economic growth in the Pooled, Fixed and Random effect models respectively. Going by the Hausman test statistics of (0.83) we accept the null hypothesis that differences in coefficient of the fixed and random estimates are not systematic, thus we accept and interpret the random effect model.

From the results presented below, a negative relationship exist between net trade and economic growth, while savings and government expenditure impacts positively on economic performance in selected West African states. However, only total savings and government expenditure are significantly related to economic performance. This relationship is statistically significant at $10 \%$ and $5 \%$ level respectively.

The results above have certain economic implications. For one, aggregate savings and government expenditure in both economies have positively influenced the growth process, but the trade gap has not been favorable. There is a high possibility that both economies import more than they export thus leading to an unfavorable balance of trade. This calls for improved external sector (foreign trade) policies. 


\section{Concluding remarks}

With the Savings-Trade-Fiscal Gap model fully explained and applied to selected West African economies, it is appropriate for all countries to eliminate fiscal dominance from monetary policy-making, reduce public debt and establish institutions that promote and encourage counter-cyclical fiscal policy, develop their financial systems, and establish credibility in fiscal and monetary policy-making. There is also urgent need to encourage international trade in terms of improved exports. This will result in increased exportation of goods and services which in the long-run will improve the economy. It is imperative to apply the Savings-Trade-Fiscal Gap Model in a typical economy.

\section{References}

Bacha, E.L. (1990), A three-gap model of foreign transfer and the GDP growth rate in developing countries, Journal of Development Economics, 32, 279-296.

Barro, R.J. (1990), Government spending in a simple model of endogenous growth, Journal of Political Economy, 95(5), 103-125.

Blejer, M., Khan, M. (1984) Government policy and private investment in developing countries, IMF Staff Papers, 31(2), 379-403.

Chenery, H.B., Strout A. (1966), Foreign assistance and economic development, American Economic Review, 55, 679-733.

Hausman,, J.A., Taylor, W.E. (1981), Panel data and unobservable individual effect, Econometrica, 49(6), 1377-1398.

Kyereboah-Coleman, A. (2007), The impact of capital structure on the performance of microfinance institutions, Journal of Risk Finance, 8, 56-71.

Mayston, D.J. (2002), Tackling the endogeneity problem when estimating the relationship between school spending and pupils' outcome, DFEE Research Report 328, Department Of Education And Skills, London.

Nakamura, M., Nakamura, A. (1981), A comparison of the labor force behavior of married women in the United States and Canada, with special attention to the impact of income taxes, Econometrica, 49, 451-489.

Rostow, W.W. (1956), The take-off into self-sustained growth, Economic Journal, 66, 25-48.

Taylor, L. (1993) (eds.) The Rocky Road to Reform, Cambridge, MIT Press. 